University of Rhode Island

DigitalCommons@URI

Open Access Master's Theses

1967

\title{
A Study to Evaluate the Effectiveness of a Remedial Clinic in Reading and Mathematics for Educationally Deprived Children
}

Ralph Ellis Anderson

University of Rhode Island

Follow this and additional works at: https://digitalcommons.uri.edu/theses

\section{Recommended Citation}

Anderson, Ralph Ellis, "A Study to Evaluate the Effectiveness of a Remedial Clinic in Reading and Mathematics for Educationally Deprived Children" (1967). Open Access Master's Theses. Paper 1161. https://digitalcommons.uri.edu/theses/1161

This Thesis is brought to you for free and open access by DigitalCommons@URI. It has been accepted for inclusion in Open Access Master's Theses by an authorized administrator of DigitalCommons@URI. For more information, please contact digitalcommons-group@uri.edu. 
A STUDY TO EVALUATE THE EFFECTIVENESS OF A RENEDIAL CLINIC IN READING AND MATHEMATICS FOR EDUCATIONALLY DEPRIVED CHILDREN

BY

RALPH ELLIS ANDERSON

A THESIS SUBNITTED IN PARTIAT FULFILLNENT OF THE REQUIREMENTS FOR THE DEGREE OF

MASTER OF ARTS

IN

GUIDANCE

UNIVERSITY OF RHODE ISLAND

1967 
MASTER OF SCIENCE THESIS

$\mathrm{OF}$

RALPH ELIIS ANDERSON

Approved:

Thesis Committee:



UNIVERSITY OF RHODE ISLAND

1967 


\section{ABSTRACT}

\section{The Problem}

The School Department of Stonington, Connecticut, initiated a remedial clinic for mathematics and reading under Title I of the Elementary and Secondary Education Act. This study explored to what degree such a facility contributed toward creating a rise in proficiency levels in mathematics and reading over a fifteen-week period of time.

\section{Procedure}

A sample of 46 students was selected from educationally deprived children who attended the remedial clinic. This sample was designated as the experimental group.

A sample of 46 students was selected from educationally deprived children who received instruction in the classroom. This sample was designated as the control group.

The difference in proficiency improvement in reading and mathematics experienced by these groups was measured over a fifteen-week period of time.

The Gray Oral Reading Test, the Ga.tes Reading Survey, and the California Arithmetic Test were administered to the experimental and control groups as pre-testing and posttesting instruments to determine degree of difference in improvement. 


\section{ronclusions}

A t-test of significance at the .05 level showed there to be a significant difference between the achievement of the experimental and control groups in reading and mathematics as registered by every test utilized. This difference favored the experimental group. 
TABLE OF CONTENTS

CHAPTER

PAGE

I. THE PROBLEM AND DEFINITION OF TERMS USED. • • • 1 Introduction. . . . . . . . . . . . . I The Problem . . . . . . . . . . . . 2

Statement of the Problem. . . . . . . . 2

Importance of the study . . . . . . . . . 2

Definition of Terms Used. . . . . . . . . . 4

Elementary and Secondary Education Act of 1965 - Title I. . . . . . . . . 4

Educationally Deprived. . . . . . . . . 4

The Clinic. . . . . . . . . . . 5

II. REVIEW OF THE IITERATURE. . . . . . . . . . . 6

Literature on Remediation in Mathematics. . . 6

Literature on Remediation in Reading. . . . . 9

III. METHODS . . . . . . . . . . . . . 18

Description of the Facility and Staff . . . 18

How Students Were Selected. . . . . . . . 19

Testing for Determining Instructional Levels. 21

Analysis of Mathematics Data. . . . . . 23

Analysis of Reading Data. . . . . . . 25

Diagnostic Testing. . . . . . . . . 25

Visual and Audiometric Testing. . . . . . 26

Groups Used . . . . . . . . . . . . 30

The Experimental Group. . . . . . . 30 
TABLE OF CONTENTS

(continued)

CHAPTER

PAGE

The Control Group. . . . . . . . . 30

Test Ma.terials Used . . . . . . . . . 31

The California Arithmetic Test . . . . . 31

The Gray Oral Reading Test . . . . . . 32

The Gates Reading Survey. . . . . . . . 32

IV. RESULTS OF STUDY. . . . • . . . . • • . . . . 34

Statistical Methods and Analysis . . . . 34

Technique . . . . . . . . . . . 34

Hypotheses . . . . . . . . . . . 34

Results of Analyses . . . . . . . . . 35

V. SUMIMARY AND CONCLUSIONS . . . . . . . . 36

Limitations of Study . . . . . . . . 37

Implications of study . . . . . . . . . 38

BIBLIOGRAPHY. . . . . . . . . . . . . . 41

APPENDIX. . . . . . . . . . . . . . . 4 43

A. Experimental Study Group. . . . . . . 43

B. Control Study Group . . . . . . . 46 


\section{IIST OF TABLES}

TABLE PAGE

I. Computer Analysis of Characteristics and

Performance in a Comparison of the Clinic and Control Groups. . . . . . . . . 35a 
THE PROBLEM AND DEFINITION OF TERMS USED

\section{INTRODUCTION}

Individuals involved in the responsibilities for educating share an increasing concern for the educationally disadvantaged child. They dedicate their efforts, therefore, to the particular need of this child: to be freed through remedial teaching and specialized services from the results of socio-economic discrimination.

In planning a program of remediation for the disadvantaged child, the main concern involved those children who had become educationally deprived because of a socioeconomic status, home environment, or a combination of these factors. These students will have had in common a long period of academic failure and a dislike for school. Either their reading digabilities are just beginning to emerge, or, in the case of the older child, will have been rooted in years of boredom and snarled by frustration. The socially idealistic pretense that these children are no different from others is no help at all. It does not help to deny the disturbing fact that human beings are not equally endowed, nor equally lucky, nor equally beautiful. Injustice occurs when one penalizes them for lacking certain intellectual powers and loses sight of them as 
human beings possessed by a full range of feeling and considerable resources of imagination.

It is with this philosophy that the stonington

School Department initiated a remedial clinic for reading and mathematics under Title I of the Elementary and Secondary Education Act.

II. THE PROBLEM

Statement of the Problem. The School Department of Stonington, Connecticut, has intiated a remedial clinic for mathematics and reading under Title I of the Elementary and Secondary Education Act. It is the purpose of this study to explore to what degree such a clinic can contribute toward creating a rise in the proficiency levels of mathematics and reading during a continuous period from October 1, 1966, to February 24, 1967.

Importance of the Study. The grade structure of any educational system assumes that all children of the same chronological age will develop to the same extent in a given period of time, regardless of ability or motivation, yet this is known to be a false assumption. There are students a.t every grade level who cannot realize their loarning potential, and this inability can usually be traced to a deficiency in the skills representing reading 
facility and the ability to reason with words. Such skills are the bases for all learning.

Reading proficiency is reached through the mastery of a succession of skills, and the child who fails to master any of these skills will fall progressively further behind his grade demands for achievement until he gives up the struggle to drop out of school and become a burden upon society -- unless remediation or retardation occurs to interrupt the sequence.

At some point more individual attention could have prevented this reading failure, but the usual class load denies a one-to-one teaching relationship. This same class load plus an absence of the techniques and aids needed prevent remediation by the classroom teacher. Retardation usually assumes a repetition of the origina, skill omissions as well as a perpetrator of psychologica,l difficulty.

Herein lies the importance of this stady -- to learn what contribution can be expected from a clinic staffed by teachers certified in remedial techniques, a clinic equipped with teaching machines, a clinic that schedules students in groups of less than five students and conducts most of its instruction on an individual basis, a clinic that ignores grade designation to instruct a student on his functional level. 
III. DEFINITION OF TERMS USED

\section{The Elementary and Secondary Education Act of 1965-}

Title I. This section of the Federal Legislation allocates money through state approval and distribution to upgrade the quality of educational opportunity for children of lowincome families. The following restrictions identify a child's eligibility:

1. Family income must be $\$ 4000$ or less.

2. Restrictive ages are 5 to 17 .

3. No distinction is made between parochial and public students, although only the public school department may receive funds as the administrative agent.

4. Community or regional centers may be created for enriching curriculums and to serve for adult education and cultural a.ctivities.

5. Basic research into the learning process and improving teaching techniques may be aided.

6. These funds can buy textbooks and other instructional materials.

Educationally Deprived. Poverty can be characterized by the absence of cultural advantages, parental apathy regarding academic achievement, and an absence of the services contributing to good health. The poor child even begins school under a disadvantage rarely to realize his 
potential, and it is not long before emotional handicaps are added to his burden.

The Clinic. The use of this term throughout this thesis will be used to designate the Educational Clinic located in Stonington, Connecticut, engaged in remediation in reading and mathematics. 
REVIEW OF THE IITERATURE

The idea of remedial teaching and the techniques involved have been with education a long time and have been recorded and validated. The clinical approach, however, as opposed to the remedial teacher operating in the school classroom, appears to be a relatively new one.

\section{LITERATURE ON REMEDIATION IN MATHEMATICS}

A conference sponsored jointly by the United States Office of Education and the National Council of Teachers of Mathematics produced the publication The Iow Achiever in Mathematics. ${ }^{l}$ This pamphlet presents remedial attempts in two cities as well as essays dealing with the motivational aspects and psychological implications involved in training the slow learner.

Baltimore, Maryland, and Fort Worth, Texas, began in 1958 and 1964 respectively to offer their seventh grades a basic program in mathematics that accentuated a more individual and diagnostic approach, a curriculum that enlarged the amount of concrete background and curtailed

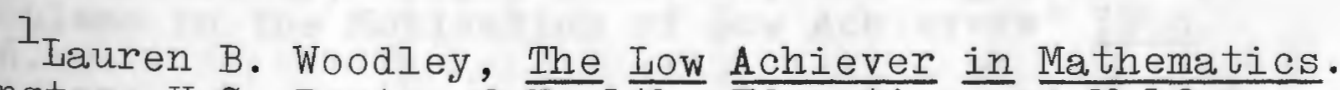
(Washington: U.S. Dept. of Health, $\frac{\text { Education }}{\text { 1965), } 1: 96 \text {. }}$. Welfare, 
the introduction of new material, and teachers chosen for their empathy for the slow learner. The articles present detailed information about the offerings in grades 7 Hrough 12, the criteria governing the selection of teachers, and the plans for evaluation when the elapse of time has made this feasible.

Dr. Jules Henry furnishes insight into why children of poverty are usually unable to achieve at the expected rate. ${ }^{2}$ The middle class in our society experiences achievement and security, but poor people do not and therefore their behavior lacks organization; theirs is a random existence. These characteristics are passed to offspring in an almost never broken cycle of hopelessness. Dr. Henry offers many insights into why the conventional classroom cannot motivate these children, insights that deal with emotions and hunger rather than curriculum choice.

Dr. Lydia Muller-Willis, a student and disciple of the Swiss psychologist Jean Piazet, in her article prescribing how a child develops his intelligence potential, casts a pertinent emphasis upon why the child of poverty

\section{${ }^{2}$ Jules Henry, "Hope, Delusion, and Organization:} Some Problems in the Motivation of Low Achievers" Ibid. p. $7: 16$. 
aperiences difficulty in school. 3 Every child goes wrough stages of learning development that begin with the discovery of an object's permanence at about 18 months, progress through thoughts of weight and shape, and reach the abstractions involved when propositions supplant objects--reasoning by using symbols. By these steps he develops his intelligence. However, a new step depends upon mastery of a preceding structure. The child of poverty zarely "gets off the ground" because he is not offered the pre-school object experiences and attention that keep interests alive.

Dr. Muller-Willis advocates going back to the child's operational level, even if such involves concrete manipulations for the pre-adolescent; encouraging the child's innate spontaneity toward discovering right from wrong; and providing the encouragement and reinforcement that lead to confidence.

Experiments in mathematics remediation instituted in St. Paul, Minnesota and Miquon, Pennsylvania, share the Femainder of this booklet with recommendations by the National Council of Teachers of Mathematics for a program to fit the low achiever. The reportings are specific as to

${ }^{3}$ Iydia Muller-Willis, "Stages in the Child's Intellectual Development: Pia.get's Views" Ibid., p. 17:22. 
mogram and ability matching. Detailed recommendations span the below-average ability and the college-bound.

\section{LITERATURE ON RENEDIATION IN READING}

Every book on the teaching of reading listed in the bibliography has borne out one fact--remedial reading instruction enlists the same techniques and the same aids as does the original reading instruction. Both approaches are identical as to the laws of application--the operating level of the student. Both recognize a poor reading ability as stemming from a single cause--the student has been advanced to a second, third, or tenth concept before mastery of the first. The remedial teacher, usually because of better diagnostic and procedural training, together with a more individualized approach, is better able to determine an operating level and has more time to allow the student to advance at his own pace. A review of the mechanics in one text is a reflection of any other text with one exception, William Kottmeyer's Teacher's Guide for Remedial Reading. This text accents remediation and the diagnostic approach, advocating the clinic framework as more efficient in results if more expensive. Dr. Kott-

4 William Kottmeyer, Teacher's Guide for Remedial Gading. (New York: Webster Division, McGraw-Hill Book 10., 1962), pp. $1-252$. 
meyer advocates barring the primary student because of his tendency to lag at the early stage and gain ground by the end of the third year. It is likely that this author is not referring to economically disadvantaged children.

\section{A Government publication, A Chance for a Change,} was written in 1965 to record some projects that have materialized under Title I of the Elementary and Secondary Education Act. 5 Eighteen projects are explained in some detail, projects that reflect the particular community's needs. College students in Tuscon, Arizona, engage in a one-to-one activity relationship with first graders.

Mentally retarded teenagers in Bloomington, Indiana, are enrolled in a work-study program. Migrant Mexican-American families are provided a special course of study. In Greencastle, Indiana, educationally deprived children are given a new physical education program and the clothes and shoes needed. In Pecos, New Mlexico, a new school bus drives poverty-stricken children from an inaccessible mountain village to school each day. Language retardation untts for pre-schoolers, improving health services for Navajos Indians, glasses and breakfasts, guidance centers for drop-outs--about 500 projects portray something of the

${ }^{5}$ United States Department of Health, Education, and Welfare, A Chance for a Change (Wa.shington, D.C., 1965), 
treatment. The book does not press upon a theory but on several, for it recognizes the complexity of the problem and the aspects of maturation involved.

The book is unique in many respects: a respect for the rhythm of growth and insight into the problems of the classroom teacher, recommendations that reading tests be eveluated qualitatively a.s well as quantitatively, that trial lessons (offered in detail) be part of the diagnostic procedure, and that a child be given an explanation of his strengths and weaknesses. This book has a spirit of warmth and empathy, a spirit so essential in handling children with reading problems.

Another aspect of uniqueness makes this book useful for teachers, reading specialists, and psychologists. Diagnosis is discussed from two angles. Chapter 2 recommends how a, teacher can diagnose an individual or a group; Chapter 3 follows the psychologists' approach. Secondly, this book is concerned with all levels. Chapter 6 includes three pupils at primary levels. Differences in approach and use of material are discussed. Chapter 8 is concerned with the older student who is almost a non-reader; Chapter 9 describes the bright high school student reading on grade level but not reaching his capabilities. Chapter 12 includes six case histories with treatment: a delinquent adolescent, a boy with maturation- 
al lag, two girls with study-skill difficulties, a boy with brain damage, and a bright high school underachiever. Throughout the text are listed children's books, workbooks, teaching devices and techniques, and games. Chapter 10 is devoted to case histories and treatment. Representative tests, selected books by grade level, and a basic sight vocabulary are provided in the appendices.

Recent Development in Reading is a compilation of the proceedings of the Twenty-Eighth Annual Conference on Reading held a.t the University of Chicago in 1965. 8 The conference evaluation holds that the remedial emphasis contained in this conference is heavy in a design to treat developmental and remedial aspects of reading instruction as parts of one total framework.

Carita Chapman of the Chicago Public Schools offers reading needs as one of the means for realizing a personal development: ${ }^{9}$

1.; An acceptable self-concept;

2. Social recognition among peers;

3. Academic competence;

4. An appreciation of the aesthetic features of

${ }^{8} \mathrm{H}$. Alan Robinson (ed.) Recent Developmentg in Read-



Ibid. ${ }^{9}$ Carita A. Chapman "Meeting Current Reading Needs" Ibid. pp. 24-28. 
Iife; and

5. A judicious use of leisure time.

Conversely, realizing these goals provide subject matter and purpose for reading, so remediation should not be confined to reading skills.

Miss Chapman suggests two methods for meeting the needs of the deficient reader:

a. The first method begins with a diagnosis of the student's reading strengths and weaknesses by using formal and informal tests. Long range instructional goals may then be set that are implemented by daily evaluations and short-term achievement goals for the confidence involved. If the student is learning, he is changing and requires changes in methods and materials continually. Throughout all of this the student should be involved in discussions of the diagnostic results and the planning so that he will be interested enough to volunteer his felt needs.

b. A second method is to have accessible many varied materials as long as it is understood the student need not peruse them from cover to cover - the goals are more important than the pattern of the materials. Science and social studies texts provide practical application of reading skills along with the sports section in the newspaper, for they demonstrate the practical implications of reading. 
Dr. Plessa.s reminds us that constant dull or phonic workbooks. without regard to the student's reading needs often passes for remediation, yet no specific weakness is clearly defined. ${ }^{10}$ word recognition, for example, includes sight recognition, context clues, and word analysis, which in turn are comprised of phonic and structural analysis skills. In a further breakdown, phonics is composed of auditory and visual associations of letters in words. These letter-sound associations involve blends, digraphs, short vowels, and long vowels, to name a few. The retarded reader never presents a simple deficiency that a single exercise can correct. Materials must be easy enough initially so as not to be a reminder of previous failure. It should be high in interest to motivate the reader, but care should be exercised. Many high-interest, low-vocabulary books introduce new words too rapidly. A major consideration would provide short drills with variety that are aimed at specific weaknesses.

Dr. Plessas makes many recommendations for instructional material. The Apen Highwa.y Books Series (Scott, Foresman) is designed to accommodate students who read below grade level. This basal series is geared to the

\footnotetext{
${ }^{10}$ Dr. Gus. P. Plessas "Using New Instructional Materials." Ibid., pp. 48-52.
} 
learning pace of retarded readers, and the sequence of skills and the developmental procedures are the same as those contained in a regular basal reader. The author recommends kits of multi-level materials, reading selections that are individualized and self-instructional, and many programmed materials. 


\section{METHODS}

In October, 1965, planning was begun; on February 1, 1966, a staff was selected to begin initial testing and parental and school contacts; and on May 1, 1966, the Educational Clinic inaugurated remediation for the educationally deprived children of the school system.

\section{DESCRIPTION OF THE FACILITY AND STAFF}

The Clinic occupies five rooms which were constructed during March and April of 1966 in an undeveloped space on the ground floor of the Mystic Junior High School. Two classrooms look through glass walls upon the expanse of a large field and surrounding woods. Three inside rooms form a main office and two utility rooms. Wall-to-wall carpeting and pastel colors decorate each room. The Clinic is staffed by a director, two remedial tea,chers for reading and one for mathematics, a guidance counselor who doubles in social service contacts, a secretary, and a bus driver. A small bus shuttles students from school to clinic and return.

This Clinic is unique with respect to any testing or instruction that existed at any time prior to the clinic's inception - unique because of its diagnostic approach. Each 
child is classified as to ability and instructional level. He is individually instructed at these levels according to the student's rate of achievement. Instructors possess a six-year degree in diagnostic and remedial techniques. Moreover, these instructors were selected for their understanding of this academically disadvantaged child and an interest in teaching him.

\section{HOW CHILDREN WERE SELECTED}

The identification of children eligible for remediation involved the following criteria:

a. The children must be from families receiving an annual income of $\$ 4,000$ or less. Ten per cent of enrollment could be admitted without regard to economic deprivation.

b. Underachievement must be indicated.

Keeping these guidelines as a control, it was then necessary to identify the attendance areas involved and the total number of children to be served. Such involved many steps:

1. Da.ta sheets were formulated and distributed to all building principals. On these sheets they were asked to list all youngsters by grade whose parents' total income did not exceed four thousand dollars. This initially had to be a subjective analysis. However, the index used 
included children presently on state aid and living in an environment generally associated with low income status. Participating in the identification procedures were the building principals, school nurses, guidance personnel, and, in several instances, the Visiting Nurses Association. When the data sheets were completed and returned to the main administration office, we had a total of two hundred and fifty-two children listed.

2. The school records of the children identified were carefully reviewed and discussed with the professional personnel.

3. All data sheets were returned to the building principals a second time for a more detailed analysis. A directive wæs issued to put a number beside the names of all children to be considered for the proposed projects. On the back of the sheet the parent's or guardian's name was listed. This was extremely helpful when we began visiting homes to explain the program.

When the data sheets were returned to the administration office the second time, the total number of children listed numbered one hundred eighty two.

4. These names were plotted on a town map with colored pins to identify the a.ttendance areas.

On the basis of the attendance analysis, the west Broad Street School of Pawcatuck and the Broadway School 
of Mystic were designated as the attendance areas to be served. The heaviest concentration of disadvantaged youth lives in the sections of town served by these schools.

of the 182 students identified, 90+ were selected as the capacity of the Clinic, and the following sequence of events occupied the staff's time during the two months preceding the Clinic's opening:

1. Parents were notified by letter of their child's assignment.

2. The children were oriented regarding plans to oring them to the Clinic.

3. The children were brought to the Clinic and shown the facility and equipment.

4. Each family was visited.

III. TESTING FOR DETERMINING INSTRUCTIONAI LEVELS

Each student involved was initially diagnostically tested for achievement in mathematics and reading, by an individual intelligence test, and screened in vision, horing and physical health. *

The underlying philosophy governing the diagnostic testing was to determine the child's capacity to learn,

* The reader may obtain copies of these data by contacting the writer at the stonington school Dept., stonington, Conn. 
what were his deficiencies in achievement, and what were the internal causes for low performance. This task required that each child be diagnostically tested, individually, using several tools to determine his achievements and specific deficiencies in reading and mathematics. In adition to his academic deficiencies each child was individually tested for intelligence and screened for vision and hearing deficiencies on a vision tester and audiometer. Each child with vision or hearing deficiencies was referred for a professional examination and treatment. The estimated time to do a complete diagnostic inventory approximated five hours.

An analysis of this initial testing, performed by the Staff and the Computer Laboratory of the University of Rhode Island, brings out some pertinent facts tha.t substantiate the premises attached to the economically-disadvantaged student.

1. Fourteen scores of the Binet were above average, 42 average, and 22 below average. Instructional results may give some indication of the feasible limits of ability for future admittance to the Clinic.

2. The correlation between the Binet, Otis and Peabody Vocabulary Tests show that the group Otis and quickly-administered Peabody cannot be 
employed for ability screenings. They apparently reflect the students verbal deficiencies. 3. The Peabody Picture Vocabulary Test does not correlate significantly with any test employed, as should be expected. It is used to determine the oral recognition vocabulary level.

4. No correlation has been learned between Gates and Nelson, but they individually show a significant relationship to the other reading tests. The C. A. T. shows a significant relationship to the reading tests, as should be expected. It has been used as a grade-level interpretation of skill gained in mathematics. The validity of the C. A. T. as a diagnostic instrument has not been determined. As a step-bystep list of skills to be mastered it can be vindicated.

\section{Analysis of Mathematics Data}

The base line data consists of numerica,l scores and a complete diagnostic inventory of skills. The numerical scores consist of grade equivalency and percentile scores. Each child has a grade equivalency score in arithmetic reasoning, fundamentals, and a total. In grade seven and eight percentile rankings were derived from the Cooperative Arithmetic Test. Together these two presented a pic- 
ture that one might expect. The scores ranged from average on parts of the test to well below on others. The average grade equivalency was about a. year below actual grade placement. Mathematical reasoning seems generally to be the lowest of all scores. This is believed to be primarily due to low reading ability.

It is interesting to note here that a correlation coefficient of about .90 exists between the grade placement score in arithmetic and instructional level for reading. This somewhat validates the earlier assumption that these areas have a high correlation.

The grade equivalency scores and percentiles were used as a basis of judging the effectiveness of the remediation when the post-testing procedure was employed. The diagnostic inventory of skills for each child is quite revealing. The findings seem to indicate that the four fundamental operations on whole numbers were not mastered with any great facility. The reasoning or basic concept was present, but the mechanical facility to solve the examples was not available to them. An example may serve to illustrate. A child solved the multiplication example twenty times thirteen by ading twenty thirteen times. Although the understanding is shown, facility in using a standard algorism was not present. This was not an isolated case of using just one operation. 
The basic combinations or number facts were not learned by the majority of cases. Most would not have any recall but would rely upon fingers, imaginary sticks, and tiles on the floor, to mention a few, to arrive at the appropriate number fact. With few exceptions most would arrive at the correct solution if given enough time.

In general, the analysis of the data seems to indicate that understanding is present, but facility is lacking.

\section{Analysis of Reading Data}

Diagnostic Testing. A battery of standardized and informal tests was administered to each child. This battery provided the clinician with a highly inclusive picture of each child's reading deficiencies.

The individual results of the diagnostic testing have been highly informative. The Cooper Diagnostic Test was intended to provide the clinician with a complete breakdown of skill deficiencies. This it has done.

The disturbing aspects of the results of the Cooper are apparent. For instance, fourteen of the seventeen first-grade children had glaring deficiencies in their readiness ba,ckground but had already entered into a forma.1 reading situation. Seven of these children were unable to recognize fifty per cent of the alphabet characters, and 
only three of the seventeen could satisfactorily pass the basal vocabulary screening at the pre-primer level. As anticipated, the major weaknesses at the other grade levels were in the areas of consonant blends and varied aspects of the vowel program.

\section{Visual and Audiometric Testing}

As part of the diagnostic inventory on all children, visual and hearing screening tests were administered. The purpose of this screening was to determine if a deficiency in vision or hearing was present that could affect academic progress. All children in the program were screened prior to admission to the Clinic using the T/O School Vision Tester. Those failing were then retested by the Clinic Nurse and referred for a professional examination. With parental permission, the students who failed were accompanied by the Nurse to a local Optometrist for a professional examination. The parents involved were then advised of the findings by the Nurse and requested to follow through with a visit to a professional man of their own choice.

The T/O School Vision Tester is an optical instrument designed for rapid and precise measurement of visual performance. The Far tests are presented at an optical distance of twenty feet and include Acuity, Fusion, Muscle Balance, Farsightedness, Color Vision and Stereo Depth. 
The Near tests at fourteen inches include Acuity and Fusion.

Audiometric screening tests were used to determine rapidly, but with reasonable accuracy, whether a person has normal hearing. All children participating in the regular Clinic program were individually screened with an audiometer. Those children who failed the test were rescreened, and an audiogram was obtained by the clinic Nurse. The parents of the children who failed the test were notified and results of tests discussed fully. With parental permission, the children were taken to an otologist for a complete examination of the ear and hearing. Recommendations were then made to the parents.

Lists of children with date of examinations and treatments were compiled to be used by the school nurses and the classroom teachers in the regular school program. The children not receiving treatment were rechecked by the school nurse.

From the outset all parties involved in any way with the Clinic were kept informed. The principals and teachers of the various schools were introduced to the Clinic and its operation by the director, who met with them at the individual schools. This set the stage for the Clinic Personnel to come into the schools to survey the records and meet with the teachers regarding individual 
papils. After children were identified for inclusion, a notice was sent to parents notifying them that their ahild was going to receive special assistance in reading or mathematics or both. The children were introduced to the Clinic by the Clinic's Counselor. A schedule was then set up with the advice and consent of the principals a.s to when was the most advisable time to take the children out of their classrooms to come to the Clinic for remediation. As the children were diagnosed, this information was sent back to the classroom teachers and another meeting wa.s scheduled between the Clinic's Staff and teachers to exlain the findings and possible courses for remediation.

As the diagnostic inventory was finished on a group of youngsters, they were brought to the Clinic for their scheduled remediation sessions. Although the school year was nearing an end, all youngsters were in the Clinic for at least four sessions. During this time the staff worked out small group and individual methods of instrucition, at the same time giving each child a sense of belonging and of accomplishment. In two cases reported to the Clinic, youngsters who had been withdrawn and permissive in the classroom became active participants. Although these are 
isolated cases, it is believed that this is indicative of the Clinic's potential.

During the diagnostic testing period a survey was conducted among the classroom teachers involved to determine how they would rate the children assigned to the Clinic with regard to psychological attributes. Each pupil was scored by his respective teacher on a five-point cale.

\section{Below Average 1, 2 Average 3 Above Average 4, 5} The composite result gave the following subjective analysis:

Attention Span . . . 2.26
Attitude Reading . . . 2.42
Attitude Math . . . 2.65
Work Habits . . . 2.12
Follows Directions . . 2.33
Initiative . . . 2.17
Peer Relationships . . 2.70

These classroom ratings came as no surprise to any one familiar with the children involved. The sudden burst from anonymity that attended assignment to sma.ll groups and individual attention brought some insight into how many students can be penalized by large-group instruction --how many can be left by the wayside. The observer must feel that the clinic could vindicate its existence if con- 
for ring confidence were its only achievement.

\section{GROUPS USED}

An Experimental Group and a Control Group have been secured as a means of measuring the degree of improvement in mathematics and reading accomplished by the Clinic over that expected from classroom instruction. Both groups received remediation for four weeks prior to June 15, 1966. Both groups attended a six-week summer session in mathematics and reading in conventional class groups. This study covers a fifteen-week period of time starting october 1, 1966 and ending February 24, 1967.

The Experimental Group. * Forty-six students who attended the clinic for remediation in mathematics and reading for a period of fifteen weeks represent the Experimental Group. They were selected from grades one through seven. They received remediation for five periods a week in each field. The periods were of forty-five minutes duration.

The Control Group. ** Forty-six students who have received instruction in the classroom since October 1, 1966

\footnotetext{
* See Appendix A

${ }^{* *}$ See Appendix B
} 
represent the Control Group. They were selected from rades one through nine.

\section{TEST MATERIALS USED}

It was originally planned to utilize one reading test, the Gray Oral Reading, as a measure for determining improvement in this field, but a review of the literature on reading rated this one aspect as inadequate. The Gates Reading survey with its factor of silent reading was added.

The California Arithmetic Test. ${ }^{1}$ Although published as a separate test, this is an extraction from the California Achievement Test Battery. It provides a sequential testing program through five levels to encompass gradelevel achievement from grade 1 through grade 9. Scores are secured for two aspects, reasoning ability and fundamentals.

This test was not selected, however, for any interpretation related to grade placement. The Clinic has been mimarily interested in the mechanics offered for pinpointing skill deficiencies, a task this test does effectively. Each question and problem contained in the test are cata-

${ }^{1}$ Ernest $W$. Tiegs and Willis W. Clark, The California Arithmetic Tests, (1957 Edition, Ca,lifornia: California Test Bureau. 
logued in a diagnostic analysis section and related to a particular involved skill.

The Gray Oral Reading Test. ${ }^{2}$ This test is designed to measure growth in oral reading, and the one test, available in 4 forms, contains gradations of difficulty to encompass grade 1 to the college level. The first three passa.ges are appropriate for grade 1 , and the next five appropriate for grades 2-6, while the last five are roughly equated to alternate grades.

The difficulty of each passage is increased by several means: difficulty of vocabulary, range and density of vocabulary, syllabic length of words, length and complexity of sentence structure and maturity of concepts. In addition to such qualitative observations, three measures have been structured objectively to facilitate the Riagnosis of reading difficulty: number of errors, elapsed time, and questions calling for the literal meaning of each passa,ge

The Gates Reading Tests. ${ }^{3}$ These are strictly diag-

${ }^{2}$ William S. Gray, Gray Ora. Reading Tests, (New York: Test Division of the Bobbs-Merrill Company, Inc., 1963.

${ }^{3}$ Arthur I. Gates, The Gates Reading Tests (New York: Bureau of Publications, Teachers College, Columbia University, I958). 
nostic in intent, although a grade level is secured, in basuring a child's ability to read silently. Three equivalent forms cover the span of grades one through ten in checking three aspects: word recognition, the acquisition of sentence meaning, and the ability to abstract a magraph meaning. No instructions are given beyond an initial example, so that meaning is necessary to enable the test taker to follow directions and to record what the test asks for. 
RESULTS OF STUDY

\section{STATISTICAL METHODS AND ANALYSES}

Technique. The Gray Oral Reading Test, the Gates Ceading Survey, and the California Arithmetic Test were administered to the experimental and control groups as pre-testing and post testing instruments to determine the comparative degrees of gain over a fifteen-week period. A t-test of significance at the .05 level was utilized through the medium of the Computer Laboratory of the University of Rhode Island to show whether or not there existed any significant difference between the gains of the experimental and control groups in reading and mathematics.

Hypotheses. The hypotheses to be tested were:

1. There is no significant difference in the reading achievement experienced by a group receiving clinical help and a group remaining in the classroom as measured by the gains reflected by the pre-testing and post-testing results of the Gray Oral Reading Test.

2. There is no significant difference in the reading achievement experienced by a group receiving clinical help and a group remaining in the classroom a,s measured by the gains reflected by the pre-testing and post-testing 
results of the Gates Reading Survey.

3. There is no significant difference in the mathematical achievement experienced by a group receiving clinical help and a group remaining in the classroom a.s measured by the gains reflected by the pre-testing and post-testing results of the California Arithmetic Test.

Results of Analyses. Table I, on the next page, contains the statistical results of the comparison between the Clinic and the Control Group. These results show a significant difference in the means of gain effected by the clinic group over that effected by the control group, even though the mean intelligence score and the mean a.ge involved favor the control group.

The Gray Oral shows a mean ga.in of 0.854 for the clinic group and 0.476 for the control group - a t of 3.420 significant below the $1 \%$ level.

The Ga,tes Survey shows a mean ga,in of .0693 for the clinic group and 0.470 for the control group - a t of 2.202 significant below the 5\% level.

The California Arithmetic shows a mean gain of 1.187 for the clinic group and 0.493 for the control group - a $t$ of 5.488 significant below the l\% level. 
TABIE I

COMPUTER ANAIYSIS OF CHARACTERISTICS AND

PERFORMANCE IN A COMPARISON OF THE

CLINIC AND CONTROI GROUPS

\begin{tabular}{lcc} 
& $\begin{array}{c}\text { Intelligence Nean } \\
\text { (wechsler) }\end{array}$ & \multicolumn{1}{c}{ Age Mean } \\
\cline { 2 - 3 } Clinic Group & 98.217 & 9.313 years \\
Control Group & 100.957 & 10.868 years \\
\hline
\end{tabular}

Means of Pre- and Post-Testing Gains

Clinic Group Control Group

t

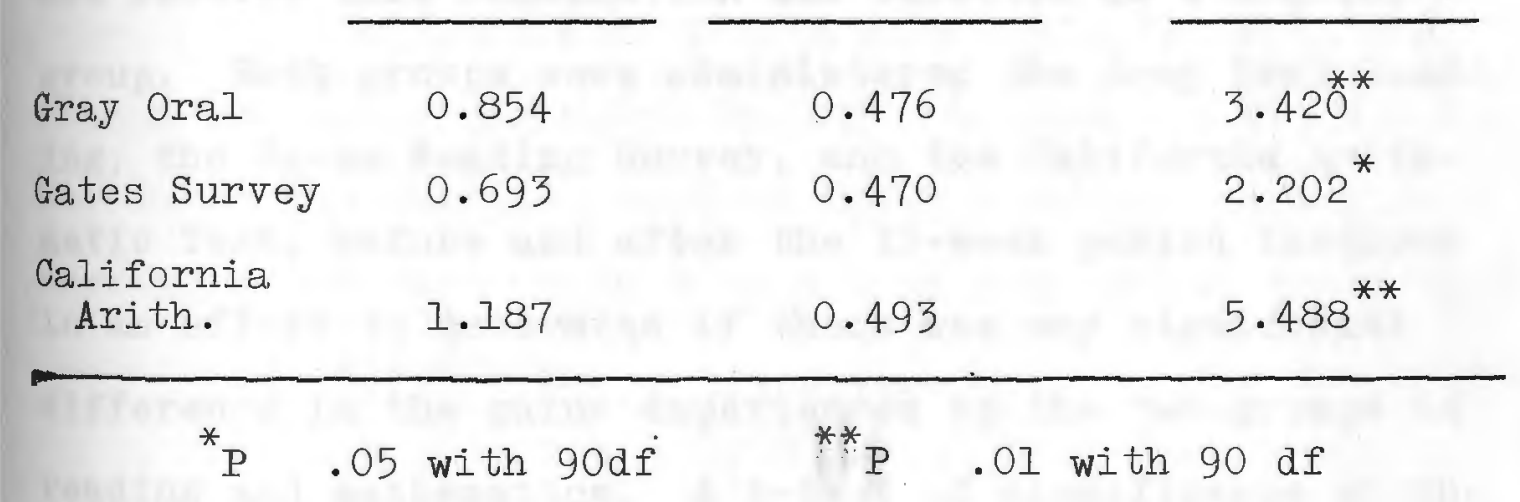




\section{$\mathrm{V}$}

SUIMIARY AND CONCLUSIONS

A study has been conducted to evaluate the effectiveness of a remedial clinic in reading and mathematics for educationally deprived children that has been in operation in the town of Stonington, Connecticut. A group of 46 students ranging from grade 1 through grade 7 that received remediation in this clinic for a fifteen-week period was selected as an experimental group. A group of 46 students ranging from grade 1 through grade 9 who did not receive this remediation was selected as a control group. Both groups were administered the Gray Oral Reading, the Ga.tes Reading Survey, and the California Arithmetic Test, before and after the 15-week period involved in an effort to determine if there was any significant difference in the gains experienced by the two groups in reading and mathematics. A t-test of significance at the .05 level shows that such a difference exists in favor of the experimental or clinic group.

That the Gray Oral Reading test shows a more significant gain between the groups than does the Gates Reading survey is possibly due to the amount of sophistication involved. The Gray Oral measured word-attack skills and is primarily a test of oral reading habits. Given a word, 
the child learns to break it into syllables and pronounce, but this test ignores whether or not he can apply these skills in the direction of reading with better understanding. The Gates Survey analyses the same criteria plus a measure of how well the child can relate to the context involved in gaining understanding as he applies these skills. The Clinic teaches skills without the use of a basal and therefore, favors the Gray Oral Test over the Gates Reading Survey.

\section{IIMITATIONS OF STUDY}

One limitation to this assumption appears in the timing factor of the Gates Survey. A lesser time needed for executing the test with an upper limit of execution remaining constant would show a gain not reflected in the results of this study.

A second limitation recognizes that the groups used were not equated statistically, for differences in age and intelligence levels were present. These differences were judged to be not obvious from empirical observation.

A third limitation has to do with the size of the groups used. Had the groups been random, the group sizes of 46 would have reflected an adequate sampling. 


\section{IMPLICATIONS OF STUDY}

The statistical limitations of this study prevent any assumption to the effect that a greater achievement or gain by one group can be attributed solely to instruction under clinical conditions. However, it gains significance as a factor deserving consideration when other subjective indications are added to this concept of the clinic being a more productive medium for improvement than the classroom--at least for the child who has not responded and performed in a larger group.

As the child has progressively fallen behind his grade, an apathy toward school work follows. Whether the apathy was induced by home environment and preceded the. school performance is impossible to tell and not too important. The Clinic's close contact with the home tends to discredit this age-old blame put upon the home, for the Clinic has found no incidence wherein the home was not grateful that an especial a.ttempt was being made to improve the child's performance. The Clinic can take full credit for strengthening a policy that takes classroom teachers into the home.

The Clinic utilizes a wide variety of teaching aids --projectors (including overhead), recorders, games, puzzles, tapes. Classroom teachers have visited the Clinic 
to learn remedial techniques, to be briefed and consulted about a particular student's difficulties, and to be introduced to the techniques for using these aids. The school district budget for 1967-68 promises that innovations will be introduced into the classrooms.

As of May 1, 1967, seventeen students have been released from the Clinic as qualified to meet the instructional levels of the classroom. Three students were unable to adjust and were returned to the Clinic. One has moved from the district. Thirteen have made a satisfactory adjustment. On June 1, 1967, 22 students will be released under the same provisions.

During the summer of 1966 the Clinic conducted a. summer session for a period of six weeks. The average attendance percentage equalled 94\%, even though the attendance was voluntary. The session of 1967 is enrolling 98\% of the Clinic group, and 26 new applicants were rejected because of the attendance limit of 110. A desire to attend school during a vacation period holds implications. The Clinic offers its students something that has not been statistically measured but appears to predicate academic improvement--a place in the sun. Each student is appraised and instructed on an individual basis. Each student is shown by the attention and love he is accorded that he matters in this scheme of things. A short time 
elapses after his admittance into the Clinic before he earns this respect. 
BIBLIOGRAPHY 


\section{BIBLIOGRAPHY}

\section{Publications of the Government}

United States Office of Education. A Chance for a Change. Washington, D. C.: U. S. Department of Health, Education and Welfare, 1965. $65 \mathrm{pp}$.

Excerpts drawn from 500 experiences in Title I projects accent the diversification possible. The accent is upon reading improvement under the assumption mathematics and other fields will follow.

Woodley, Lamen. The Low Achiever in Mathematics. Washington, D. C.: U. S. Department of Health, Education and Welfare, 1965. $95 \mathrm{pp}$.

This publication, Bulletin \#31, resulted from a joint meeting of the United States Office of Education and the National Council of Teachers in Mathematics. It contains philosophies of industry and educators regarding the low and under-achiever, measures for combating the causes for drop-out, and experiences in mathematics remediation in five school districts.

\section{2. $\underline{\text { Books }}$}

Durrell, Donald. Improving Reading Instruction. New York: Harcourt, Brace, and World, 1956.

An accent on the development rather than remedial approa.ch to teaching reading in which remedial, clinical, and classroom instruction are given no distinctive connotations.

Gray, William S. On Their Own in Reading. Chicago, Illinois: Scott, Foresman and Company, 1960 (Revised Edition). 242 pp.

Concentrating upon the first two years of reading instruction, this book offers a condensed and detailed approach with the accent upon independence in analyzing new words.

Kottmeyer, William. The Teacher's Guide for Remedial Reading. New York: The McGraw-Hill Company, 1959. $264 \mathrm{pp}$.

The author summarizes suggestions for reading programs drawn from his experience as superintendant of schools. This text alone supports the clinic approach 
Robinson, H. Alan. Recent Developments in Reading.

Chicago: The University of Chicago Press, 1965.

$239 \mathrm{pp}$.

This book is a compilation of the proceedings of the Twenty-Eighth Annual Conference in Reading

held at the University of Chicago in 1965. An evaluation of this conference holds that the remedial emphasis contained in this conference is heavy in a. design to treat developmental and remedial aspects of reading instruction as parts of one total framework.

Roswell, Florence and Gladys Nachez. Reading Disability. New York: Basic Books, Inc., 1964. $218 \mathrm{pp}$.

This text is directed exclusively toward the child who has drifted into trouble. The focus is on reading disability in contrast with developing reading skills in a sequence for the normal learner, and the reader is led through the cause, diagnosis, and treatment for many reading difficulties.

Traxler, Arthur E. and Ann Jungeblut. Research In Reading During Another Four Years. New York: Educational Records Bureau, 1960.218 pp.

This report lists the references information for 438 theses written on reading from 1953 to 1957 and summarizes the findings for each. The authors group the topics according to subject and comment upon the findings. 


\section{APPENDIX}


STATISTICAI DATA

EXPERIMENTAL STUDY GROUP

\begin{tabular}{|c|c|c|c|c|c|c|c|c|c|}
\hline $\begin{array}{l}\text { Student } \\
\text { Number }\end{array}$ & Wechsler & Age & Grade & $\begin{array}{l}\text { Initial } \\
\text { Gray Ora, }\end{array}$ & $\begin{array}{c}\text { Fina.1 } \\
\text { Gra.y Ora,I }\end{array}$ & $\begin{array}{c}\text { Initia,I } \\
\text { Gates }\end{array}$ & $\begin{array}{l}\text { Fina.1. } \\
\text { Gates }\end{array}$ & $\begin{array}{l}\text { Initial } \\
\text { Math }\end{array}$ & $\begin{array}{l}\text { Final } \\
\text { Ma,th }\end{array}$ \\
\hline 10802 & 111 & $6-3$ & 1 & 0.0 & 0.0 & 0.0 & 1.0 & 1.0 & 1.4 \\
\hline 10903 & 85 & $7-2$ & 1 & 0.0 & 0.0 & 0.0 & 0.0 & 0.9 & 2.1 \\
\hline 10009 & 72 & $6-4$ & $I$ & 0.0 & 0.0 & 0.0 & 0.0 & 0.0 & 0.6 \\
\hline 11505 & 86 & $7-3$ & 1 & 0.0 & 0.0 & 0.0 & 0.0 & 0.2 & 1.2 \\
\hline 10106 & 96 & $6-4$ & 1 & 0.0 & 1.6 & 0.0 & 1.5 & 0.1 & 1.1 \\
\hline 21007 & 109 & $6-2$ & 2 & 1.0 & 1.6 & 1.6 & 2.0 & 1.4 & 2.8 \\
\hline 20504 & 144 & $6-10$ & 2 & 1.0 & 1.2 & 2.1 & 2.3 & 1.7 & 2.1 \\
\hline 20403 & 107 & $6-5$ & 2 & 1.0 & 1.6 & 2.1 & 2.6 & 1.0 & 1.4 \\
\hline 20706 & 113 & $7-4$ & 2. & 1.0 & 1.6 & 2.2 & 2.6 & $2 \cdot 3$ & 2.8 \\
\hline 20605 & 124 & $6-5$ & 2 & 0.0 & 1.0 & 0.0 & 2.1 & 1.6 & 2.6 \\
\hline 20014 & 82 & $7-6$ & 2 & 0.0 & 0.5 & 1.0 & 1.3 & 1.0 & 1.6 \\
\hline 22415 & 97 & $8-11$ & 2 & 0.0 & 1.0 & 1.0 & 1.6 & 1.3 & 2.1 \\
\hline 22917 & 65 & $9-8$ & 2 & 1.0 & 1.2 & 1.7 & 1.7 & 0.5 & 1.1 \\
\hline 21713 & 84 & $8-7$ & 2 & 0.5 & 1.2 & 1.9 & $2 \cdot 3$ & 1.5 & 2.8 \\
\hline 22616 & 102 & $7-7$ & 2 & 0.5 & 1.6 & $2 \cdot 3$ & 2.6 & 1.9 & $3 . \dot{3}$ \\
\hline 21612 & 100 & $6-10$ & 2 & 0.5 & 1.1 & 1.5 & 2.3 & 1.2 & 1.5 \\
\hline 21209 & 114 & $7-5$ & 2 & 0.5 & 1.6 & 1.7 & 2.8 & 1.7 & 2.9 \\
\hline
\end{tabular}


(continued)

\begin{tabular}{|c|c|c|c|c|c|c|c|c|c|}
\hline $\begin{array}{l}\text { Student } \\
\text { Number }\end{array}$ & Wechsler & Age & Grade & $\begin{array}{l}\text { Initial } \\
\text { Gray Oral }\end{array}$ & $\begin{array}{l}\text { Final } \\
\text { Gray Ora.1 }\end{array}$ & $\begin{array}{c}\text { Initial } \\
\text { Gates }\end{array}$ & $\begin{array}{l}\text { Final } \\
\text { Gates }\end{array}$ & $\begin{array}{l}\text { Initial } \\
\text { Math }\end{array}$ & $\begin{array}{l}\text { Fina, } \\
\text { Ma.th }\end{array}$ \\
\hline 21108 & 104 & $7-8$ & 2 & 0.0 & 1.0 & 0.6 & 1.8 & 1.6 & 2.8 \\
\hline 20201 & 90 & $6-9$ & 2 & 0.0 & 0.0 & 0.0 & 0.5 & 0.6 & 2.0 \\
\hline 21820 & 111 & $7-11$ & 2 & 1.4 & 2.1 & 2.2 & 3.2 & 1.7 & 2.9 \\
\hline 30010 & 117 & $10-1$ & 3 & 3.2 & 5.6 & 3.6 & 6.2 & 3.0 & 5.8 \\
\hline 32706 & 122 & $7-9$ & 3 & 1.3 & 2.1 & 2.9 & 4.0 & 3.2 & 4.6 \\
\hline 32203 & 110 & $9-11$ & 3 & 1.7 & 2.9 & 2.2 & 3.1 & 3.2 & 4.4 \\
\hline 33608 & 77 & $10-7$ & 3 & 1.9 & 2.0 & 2.5 & 3.0 & 3.6 & 3.9 \\
\hline 32304 & 100 & $8-6$ & 3 & 3.0 & 4.0 & $4 \cdot 4$ & 4.8 & 1.6 & 4.0 \\
\hline 31901 & 86 & $8-7$ & 3 & 0.5 & 1.5 & 1.5 & 2.9 & 1.0 & 1.5 \\
\hline 32002 & 112 & $8-2$ & 3 & 1.0 & 1.5 & 1.8 & 2.4 & 1.6 & 4.0 \\
\hline 44208 & 87 & $11-0$ & $4^{\circ}$ & $2 \cdot 3$ & 3.6 & 3.0 & 4.1 & 3.2 & 5.4 \\
\hline 43403 & 91 & $10-9$ & 4 & 2.3 & 2.8 & 3.9 & 4.1 & 3.5 & $4 \cdot 3$ \\
\hline 33709 & 94 & $9-4$ & 4 & 2.2 & 2.6 & 3.1 & 3.5 & 3.8 & 4.1 \\
\hline 43504 & 109 & $9-4$ & 4 & 3.0 & 3.6 & $4 \cdot 3$ & 4.6 & 3.9 & 5.4 \\
\hline 44006 & 111 & $8-10$ & 4 & 2.3 & 3.9 & 4.1 & 4.6 & 4.0 & 5.8 \\
\hline 33709 & 104 & $9-4$ & 4 & 2.2 & 3.2 & 3.1 & 3.8 & 3.8 & 5.4 \\
\hline 54803 & 120 & $10-9$ & 5 & 6.0 & 6.8 & 4.3 & 6.8 & 6.6 & 7.2 \\
\hline
\end{tabular}


(continued)

\begin{tabular}{|c|c|c|c|c|c|c|c|c|c|}
\hline $\begin{array}{l}\text { Student } \\
\text { Number }\end{array}$ & Wechsler & Age & Grade & $\begin{array}{l}\text { Initial } \\
\text { Gray Oral }\end{array}$ & $\begin{array}{c}\text { Fina.l } \\
\text { Gra.y Oral }\end{array}$ & $\begin{array}{c}\text { Initial } \\
\text { Gates }\end{array}$ & $\begin{array}{l}\text { Final } \\
\text { Gates }\end{array}$ & $\begin{array}{l}\text { Initial } \\
\text { Math }\end{array}$ & $\begin{array}{l}\text { Fina.1 } \\
\text { Ma,th }\end{array}$ \\
\hline 55005 & 107 & $9-9$ & 5 & 3.2 & 5.2 & 4.5 & 5.2 & 5.6 & 7.0 \\
\hline 65605 & 64 & $11-2$ & 6 & 4.8 & 6.6 & 4.7 & 5.4 & 5.0 & 5.2 \\
\hline 65202 & 69 & $13-5$ & 6 & 2.6 & 3.0 & 3.3 & 3.6 & 4.2 & 4.8 \\
\hline 65404 & 104 & $10-9$ & 6 & 3.1 & 5.2 & 5.0 & 5.4 & 4.9 & 6.2 \\
\hline 77109 & 71 & $14-0$ & 7 & 5.7 & 5.9 & 4.9 & 5.2 & 4.7 & 5.1 \\
\hline 77210 & 90 & $12-0$ & 7 & 6.0 & 6.5 & 6.2 & 6.8 & 5.8 & 6.8 \\
\hline 77513 & 103 & $12-8$ & 7 & 4.8 & 7.4 & 6.0 & 6.5 & 6.5 & 7.4 \\
\hline 76402 & 107 & $14-10$ & 7 & 9.5 & 9.5 & 8.2 & 9.4 & 4.9 & 8.3 \\
\hline 76907 & 104 & $12-8$ & .7 & 4.4 & 5.4 & 5.5 & 5.8 & 5.3 & 7.6 \\
\hline 76604 & 98 & $12-7$ & 7. & 2.6 & 5.6 & 6.6 & 7.1 & 4.9 & 6.8 \\
\hline 76806 & 86 & $12-8$ & 7 & 7.2 & 7.8 & 5.8 & 6.1 & 5.4 & 7.1 \\
\hline 76503 & 79 & $13-8$ & 7 & 1.7 & 2.1 & 2.0 & 2.6 & 3.9 & 5.7 \\
\hline
\end{tabular}




\begin{tabular}{|c|c|c|c|c|c|c|c|c|c|}
\hline $\begin{array}{l}\text { Student } \\
\text { Number }\end{array}$ & Wechsler & Age & Grade & $\begin{array}{l}\text { Initial } \\
\text { Gray Oral }\end{array}$ & $\begin{array}{c}\text { Fina.1 } \\
\text { Gra.y Ora.1 }\end{array}$ & $\begin{array}{c}\text { Initial } \\
\text { Ga.tes }\end{array}$ & $\begin{array}{l}\text { Final } \\
\text { Ga.tes }\end{array}$ & $\begin{array}{l}\text { Initia.I } \\
\text { Ma.th }\end{array}$ & $\begin{array}{l}\text { Final } \\
\text { Ma.th }\end{array}$ \\
\hline 10004 & 78 & $8-2$ & 1 & 0.0 & 0.0 & 0.0 & 0.5 & 0.9 & 1.4 \\
\hline 10007 & 93 & $7-0$ & 1 & 0.0 & 0.5 & 0.5 & 1.0 & 1.1 & 1.4 \\
\hline 10008 & 96 & $6-11$ & 1 & 0.0 & 0.5 & 1.0 & 1.3 & 0.9 & 1.3 \\
\hline 10106 & 96 & $6-5$ & 1 & 0.0 & 0.5 & 0.6 & 0.6 & 1.1 & 1.3 \\
\hline 20011 & 96 & $8-8$ & 2 & 0.0 & 0.5 & 0.0 & 1.0 & 2.8 & 3.0 \\
\hline 20018 & 66 & $9-7$ & 2 & 0.5 & 1.1 & 1.6 & 2.0 & 1.0 & 1.2 \\
\hline 20019 & 125 & $9-7$ & 2 & 1.0 & 1.5 & 1.5 & 2.0 & 2.5 & 3.2 \\
\hline 20302 & 108 & $6-8$ & 2 & 0.5 & 1.0 & 1.7 & 2.0 & 1.1 & 1.8 \\
\hline 21310 & 106 & $6-8$ & $2^{\circ}$ & 0.5 & 1.1 & 2.3 & 2.5 & 2.0 & 2.3 \\
\hline 30011 & 86 & $10-0$ & 3 & 1.2 & 1.7 & 0.5 & 1.0 & 2.2 & 2.4 \\
\hline 30012 & 96 & $9-5$ & 3 & 1.3 & 1.6 & 2.4 & 2.8 & 3.0 & 3.0 \\
\hline 32505 & 116 & $7-10$ & 3 & 0.5 & 1.4 & 2.3 & 2.6 & 3.2 & 4.0 \\
\hline 32706 & 122 & $7-9$ & 3 & 1.3 & 2.5 & 2.9 & 3.3 & 4.0 & 4.9 \\
\hline 33107 & 97 & $8-4$ & 3 & 0.5 & 1.0 & 2.0 & 2.3 & 1.4 & 3.1 \\
\hline 40011 & 109 & $10-6$ & 4 & 1.9 & 2.0 & 1.9 & 2.2 & 3.4 & 3.8 \\
\hline 43201 & 99 & $10-1$ & 4 & 3.2 & 3.2 & 3.3 & 3.8 & $4 \cdot 4$ & 4.7 \\
\hline
\end{tabular}


(continued)

\begin{tabular}{|c|c|c|c|c|c|c|c|c|c|}
\hline $\begin{array}{l}\text { Student } \\
\text { Number }\end{array}$ & Wechsler & Age & Grade & $\begin{array}{l}\text { Initial } \\
\text { Gray Oral }\end{array}$ & $\begin{array}{c}\text { Final } \\
\text { Gray Oral }\end{array}$ & $\begin{array}{c}\text { Initial } \\
\text { Gates }\end{array}$ & $\begin{array}{l}\text { Final } \\
\text { Gates }\end{array}$ & $\begin{array}{l}\text { Initia.l } \\
\text { Ma.th }\end{array}$ & $\begin{array}{r}\text { Final } \\
\text { Ma.th }\end{array}$ \\
\hline 43202 & 82 & $9-7$ & 4 & 2.2 & 2.5 & 2.3 & 2.5 & 3.2 & 3.2 \\
\hline 44409 & 85 & $10-2$ & 4 & 2.7 & 2.9 & 2.9 & 3.1 & 3.0 & 3.4 \\
\hline 43805 & 99 & $9-3$ & 4 & 1.2 & 2.3 & 3.5 & 3.8 & 3.5 & 4.0 \\
\hline 44610 & 80 & $12-1$ & 4 & 3.0 & $4 \cdot 3$ & 2.1 & 2.5 & 5.0 & 5.3 \\
\hline 50007 & 111 & $11-10$ & 5 & 2.8 & 3.1 & 3.5 & 3.9 & 4.9 & 4.9 \\
\hline 53906 & 118 & $9-4$ & 5 & 1.0 & 2.0 & 2.8 & 3.1 & 5.5 & 6.2 \\
\hline 50008 & 101 & $10-8$ & 5 & 2.7 & 3.2 & 3.0 & 3.4 & 4.6 & 4.9 \\
\hline 54702 & 95 & $10-5$ & 5 & $2 . .4$ & 2.6 & 2.5 & 4.6 & 3.3 & 4.2 \\
\hline 54501 & 94 & $10-5$ & 5 & 3.0 & 3.4 & 4.5 & 5.3 & $4 \cdot 2$ & 4.8 \\
\hline 66210 & 126 & $13-1$ & 6 & $4 \cdot 4$ & 4.8 & 4.8 & 6.8 & 6.6 & 7.2 \\
\hline 66109 & 99 & $10-9$ & 6 & 6.6 & 6.8 & 6.1 & 6.4 & 6.3 & 6.3 \\
\hline 65807 & 143 & $10-5$ & 6 & 5.8 & 6.2 & 5.2 & 6.0 & 5.2 & 6.8 \\
\hline 65101 & 96 & $11-0$ & 6 & 5.6 & 6.0 & 4.9 & 5.2 & 4.9 & 6.4 \\
\hline 65706 & 99 & $12-3$ & 6 & 3.8 & $4 \cdot 3$ & 4.2 & 4.5 & 5.0 & 5.5 \\
\hline 66008 & 89 & $12-4$ & 6 & 3.7 & 3.9 & 5.1 & $4 \cdot 3$ & 5.5 & 5.5 \\
\hline 65303 & 75 & $12-2$ & 6 & 0.5 & 1.5 & 4.2 & 4.6 & 4.6 & 4.8 \\
\hline 70018 & 125 & $12-8$ & 7 & 11.7 & 12.2 & 8.6 & 9.0 & 5.7 & 5.9 \\
\hline
\end{tabular}


(continued)

\begin{tabular}{|c|c|c|c|c|c|c|c|c|c|}
\hline $\begin{array}{l}\text { Student } \\
\text { Number }\end{array}$ & Wechsler & Age & Gra.de & $\begin{array}{l}\text { Initial } \\
\text { Gray Ora.I }\end{array}$ & $\begin{array}{c}\text { Final } \\
\text { Gra.y Oral }\end{array}$ & $\begin{array}{c}\text { Initia.l } \\
\text { Gates }\end{array}$ & $\begin{array}{l}\text { Fina.l } \\
\text { Gates }\end{array}$ & $\begin{array}{l}\text { Initia.I } \\
\text { Ma.th }\end{array}$ & $\begin{array}{l}\text { Final } \\
\text { Ma.th }\end{array}$ \\
\hline 77816 & 100 & $12-9$ & 7 & 8.0 & 8.0 & 8.5 & 8.6 & 6.0 & 6.3 \\
\hline 76301 & 98 & $12-11$ & 7 & 4.2 & 5.0 & 6.0 & 6.2 & 5.6 & 6.0 \\
\hline 70017 & 115 & $13-1$ & 7 & 5.5 & 5.8 & 9.0 & 9.4 & $7 \cdot 4$ & 7.8 \\
\hline 77115 & 138 & $12-7$ & 7 & 6.6 & 7.0 & 5.6 & 6.5 & 6.7 & 6.7 \\
\hline 77311 & 89 & $12-0$ & 7 & 6.4 & 6.8 & 6.7 & 6.8 & 7.0 & 7.5 \\
\hline 77614 & 115 & $11-7$ & 7 & 8.6 & 8.6 & 9.0 & 9.0 & $7 \cdot 3$ & 8.3 \\
\hline 88303 & 92 & $14-5$ & 8 & $4 \cdot 4$ & 4.8 & 5.7 & 6.8 & 5.2 & 5.4 \\
\hline 88002 & 98 & $14-2$ & 8 & 3.2 & $4 \cdot 2$ & 2.9 & 4.0 & $7 \cdot 3$ & 7.6 \\
\hline 89106 & 105 & $13-11$ & 8 & 7.0 & 7.0 & $4 \cdot 7$ & -5.0 & 6.3 & $7 \cdot 7$ \\
\hline 98502 & 107 & $14-7$ & 9. & 2.5 & 3.2 & $4 \cdot 6$ & 4.8 & $7 \cdot 5$ & 7.5 \\
\hline 98603 & 92 & $15-7$ & 9 & 2.8 & 2.8 & $4 \cdot 5$ & 5.0 & $7 \cdot 3$ & 7.5 \\
\hline 98906 & 95 & $15-5$ & 9 & 4.7 & 5.4 & 6.8 & 7.2 & 5.9 & 7.4 \\
\hline
\end{tabular}

